\title{
Effects of Gamma Irradiated and Non-Irradiated Sewage Sludge on Essential Oil Content and Constituents of Ocimum basilicum L.
}

\author{
Asgari Lajayer B (Ph.D.) ${ }^{1}$, Najafi NA (Ph.D.) ${ }^{1 *}$, Moghiseh E (Ph.D.) ${ }^{2}$, Mosaferi M (Ph.D.) ${ }^{3}$, \\ Hadian J (Ph.D.) ${ }^{4}$
}

1- Department of Soil Science, Faculty of Agriculture, University of Tabriz, Tabriz, Iran

2- Nuclear Agriculture Research School, Nuclear Science and Technology Research

Institute, Karaj, Iran

3- Health and Environment Research Center, Tabriz University of Medical Sciences,

Tabriz, Iran

4- Medicinal Plants and Drugs Research Institute, Shahid Beheshti University, Tehran, Iran

*Corresponding author: Department of Soil Science, Faculty of Agriculture,

University of Tabriz, Tabriz, Iran

Tel: +98-41-33392025, Fax: +98-41-33345332

E-mail: n-najafi@tabrizu.ac.ir

Received: 9 Oct. 2018

Accepted: 5 May 2019 doi: 10.29252/jmp.3.71.99

Abstract

Background: The increasing amount of sewage sludge (SS) and more legislative regulation of its disposal have stimulated the need for developing new technologies including gamma irradiation to recycle SS efficiently.

Objective: To evaluate the effects of gamma irradiated and non-irradiated SS (SSGI and SSNI, respectively) on essential oil (EO) content and composition of Ocimum basilicum $\mathrm{L}$.

Methods: A greenhouse experiment was conducted with 15,30 , and $60 \mathrm{~g} \mathrm{~kg}^{-1} \mathrm{of} \mathrm{SS}$ irradiated with absorbed doses of 5, 10, and $20 \mathrm{kGy}$ gamma-ray and soil without SS and irradiation as the control treatment. The essential oil was isolated by hydro-distillation and analyzed by Gas chromatography and Gas chromatography-mass spectrometry techniques.

Results: The applications of SSGI and SSNI at all levels except $15 \mathrm{~g} \mathrm{~kg}^{-1}$ significantly enhanced EO content compared to the control. The using of $60 \mathrm{~g} \mathrm{~kg}^{-1} \mathrm{SS}$ in each absorbed dose significantly reduced EO yield relative to the control, while it was significantly increased under 15 and $30 \mathrm{~g} \mathrm{~kg}^{-1}$ SSNI and SSGI. Also, in $60 \mathrm{~g} \mathrm{SS} \mathrm{kg}^{-1}$, the restriction effects on EO yield were mitigated with increasing the absorbed dose of gamma-ray, but it was insignificant with increasing absorbed dose to 10 and 20 relative to $5 \mathrm{kGy}$. The methyl chavicol as a major constituent of EO was significantly increased in SSGI and SSNI as compared with the control. However, the increment in the methyl chavicol content was not significant between the treatments $\geq 30 \mathrm{~g} \mathrm{~kg}^{-1}$ SSGI or SSNI and $15 \mathrm{~g} \mathrm{~kg}^{-1}$ SS at absorbed dose of $\geq \mathbf{1 0} \mathrm{kGy}$.

Conclusion: To improve essential oil content and composition, application of $\leq 30 \mathrm{~g} \mathrm{~kg}^{-1}$ sewage sludge with $5 \mathrm{kGy}$ absorbed dose of gamma-ray can be suggested at similar conditions.

Keywords: Basil, Essential oil, Gamma irradiation, Medicinal plant, Sewage sludge 


\section{Introduction}

The disposal of sewage sludge (SS) has increased dramatically in a human environment due to the rapid growth of industrialization and urbanization [1]. The SS is produced by wastewater treatment processes (WWTPs), where solids and liquids are separated [2]. The sludge produced by WWTPs including primary and secondary sludge is usually processed via aerobic and anaerobic digestion to reduce the water content, stabilize the organic matter in the final product and be disinfected; thus it becomes suitable for final disposal and utilization in agriculture [3]. In general, SS consists organic matter, macro- and micronutrients, and therefore can be utilized in agricultural lands as organic fertilizer to produce better yield especially in the lighttextured sandy soils [4]. However, the utilization of SS in agricultural lands could create a few environmental and public health concerns through entering pathogenic bacteria and viruses [5], toxic organic substances and heavy metals (HMs) to the food chain and/or environment [6, 7], due to not completely successful reducing biological and chemical contamination of SS to the desired levels [8]. Ionizing radiation technology especially gamma-ray is regarded as a promising alternative, effective and rapid method of SS treatment [9]. The gamma radiation can cause the following events in SS: (i) inactivation of microbial populations; (ii) oxidation of organic compounds, which can result in the formation of $\mathrm{CO}_{2}$ and $\mathrm{H}_{2} \mathrm{O}$ [10] (iii) degradation of the SS structure, promoting the release of more easily adsorbed free forms of metals derived from the degradation of soluble organic complexes thereby altering mobility of HMs and micronutrients [6].

On the other hand, SS is mainly used in cultivation of vegetables due to its low cost in Iran. Basil (Ocimum basilicum L.), a wellknown vegetable and/or non-food crop (medicinal and aromatic plant) belonging to Lamiaceae family [11]. Further, due to the transfer of potential contaminants in SS into the human food chain directly via uptake from agricultural soils, its application to non-food crops seems of great potential [12]. Since the harvested foliage of medicinal and aromatic plants is a source of essential oil (EO) (the marketable revenue-generating products of aromatic), and EO is free from the risk of heavy metals accumulation from initial plant biomass $[13,14]$. The previous studies mostly focused on the effects of non-irradiated SS (SSNI) and other organic materials including farmyard manure, poultry manure and vermicompost on EO production and chemical composition of medicinal plants EOs [15-18]. Therefore, there exist very sparse if any reliable and comprehensive data regarding the use of gamma irradiated SS (SSGI) on secondary metabolite biosynthesis of basil plant. Hence, this study aims to evaluate the effects of gamma irradiated and non-irradiated sewage sludge on essential oil production and constituents of basil plant.

\section{Materials and Methods}

\section{Materials}

All the chemicals (e.g. diethylenetriaminepentaacetic acid (DTPA), sodium bicarbonate, ammonium acetate, hydrochloric acid, nitric acid, sodium 
hexametaphosphate, sulfuric acid, ferrous sulfate, sodium hydroxide, potassium antimony tartrate, and potassium dihydrogen phosphate) were purchased from Merck Company, Germany.

\section{Experimental set up}

A pot experiment was conducted in a naturally lighted greenhouse at Nuclear Agriculture Research School, Nuclear Science and Technology Research Institute, Karaj, Iran during November 2017. Basil seeds (O. basilicum L.) after providing from Pakan Bazr Company, Esfahan, Iran were cultivated in chest and after reaching the three-leaf stage, four uniform seedlings were transplanted in each pot. Plastic pots with diameter and height of 15 and $18 \mathrm{~cm}$, respectively, were used and filled with $3 \mathrm{~kg}$ of dried soil. The pots were randomly rotated on a weekly basis in the benches to avoid any potential localized effects on plants. The seedlings were irrigated daily with distilled water to $70-80 \%$ field capacity by weighing the pots. The plants were harvested at the fully flowering growth stage ( 12 weeks after sowing), when the quantity and quality of essential oil (EO) are usually maximum. At harvest, the aboveground plant parts were carefully cut at $2-3 \mathrm{~cm}$ above the pot soil level and half of the shoot was shade dried for 14 days at room temperature $\left(20-25{ }^{\circ} \mathrm{C}\right)$ and distilled for EO extraction. The second half of the vegetative tissue were oven-dried $\left(70{ }^{\circ} \mathrm{C}\right.$ for $72 \mathrm{~h}$ ) and subsequently weighed using a digital precision scale $( \pm 0.0001 \mathrm{~g})$. Then the roots were carefully separated from the soil and to prevent losses of hairy roots, it was washed on the sieve with distilled water and dried in a ventilated oven at $70{ }^{\circ} \mathrm{C}$ to a constant weight. Finally, after drying, the samples were ground and sieved by a $0.5 \mathrm{~mm}$ sieve and stored in polyethylene bottles at room temperature for further analyses.

\section{Gamma irradiation of sewage sludge and treatment details}

Sewage sludge (SS) was collected from Southern Municipal Wastewater Treatment Plant of Tehran, Iran. The wastewater treatment processes of the plant involve gravity and pumping, screening, grit, oil, fat and grease removal, primary sedimentation, aeration tanks and activated sludge, trickling filters, secondary sedimentation and chlorination unit. Also, in order to treat the sludge, Southern Municipal Wastewater Treatment Plant of Tehran has adopted a gravitational condensation of sludge produced from preliminary and secondary treatment, anaerobic digester, storage and stabilization, dewatering with belt filter press and storing dewatered sludge for further drying. The examined SS was collected by a sterilized special recipient immediately after the dewatering treatment.

Gamma irradiation was performed at room temperature from a Gamma Cell ${ }^{60} \mathrm{Co}$ source with a dose rate of $124 \mathrm{~Gy} \mathrm{~min}^{-1}$ and specific activity of 8677 Curie with different absorbed doses of 0, 5, 10 and $20 \mathrm{kGy}$ in the Nuclear Science and Technology Research Institute, Atomic Energy Organization of Iran. Since 10 kGy absorbed dose of gamma radiation has been recommended by United States Environmental Protection Agency (USEPA) as a process to further reduce pathogens in municipal sludge [19]; and considering the 
trend of changes in SS properties following gamma irradiation, it was irradiated with half of the recommended dose, the recommended dose and twice the recommended dose of USEPA. The dose of irradiation was determined by the standard Fricke dosimeter.

Both SSGI and SSNI were applied at levels of $0,15,30$, and $60 \mathrm{~g} \mathrm{~kg}^{-1}$ soil (approximately equivalent to $0,30,60$, and 120 tons $\mathrm{dw} \mathrm{ha}^{-1}$ ). Totally, the experiment consisted of 13 treatments which were applied as: soil without SS and irradiation as the control, 15, 30, and 60 $\mathrm{g} \mathrm{kg}^{-1}$ of SSNI (abbreviated as $\mathrm{SS}_{15} \mathrm{NI}, \mathrm{SS}_{30} \mathrm{NI}$ and $\mathrm{SS}_{60} \mathrm{NI}$, respectively), irradiated with 5 kGy (abbreviated as $\mathrm{SS}_{15} \mathrm{GI}_{5}, \mathrm{SS}_{30} \mathrm{GI}_{5}$ and $\mathrm{SS}_{60} \mathrm{GI}_{5}$, respectively), $10 \mathrm{kGy}$ (abbreviated as $\mathrm{SS}_{15} \mathrm{GI}_{10}, \mathrm{SS}_{30} \mathrm{GI}_{10}$ and $\mathrm{SS}_{60} \mathrm{GI}_{10}$, respectively) and $20 \mathrm{kGy}$ (abbreviated as $\mathrm{SS}_{15} \mathrm{GI}_{20}, \mathrm{SS}_{30} \mathrm{GI}_{20}$ and $\mathrm{SS}_{60} \mathrm{GI}_{20}$, respectively).

\section{Essential oil extraction and analysis Essential oil extraction}

The EO of $O$. basilicum plants (one half of the air dried shoot) was isolated by hydrodistillation for $3 \mathrm{~h}$ using a Clevenger-type apparatus according to the method recommended by British Pharmacopoeia [20]. The isolated oil was dried over anhydrous sodium sulfate and then stored in tightly closed dark vials at $4{ }^{\circ} \mathrm{C}$ in the refrigerator until analysis. The essential oil yield was computed by multiplying the dry shoot yield by the oil content.

\section{Gas chromatography analysis}

Gas chromatography (GC) analysis was performed using a Thermoquest-Finnigan gas chromatograph, Model 2000, USA, with a flame ionization detector (FID). The analysis was carried out on fused silica capillary DB-5 column (30 m (length) $\times 0.25 \mathrm{~mm}$ (internal diameter), and film thickness of $0.25 \mu \mathrm{m}$ ). The injector and detector temperatures were kept at $250{ }^{\circ} \mathrm{C}$ and $300{ }^{\circ} \mathrm{C}$, respectively. Nitrogen was used as the carrier gas at a flow rate of $1.1 \mathrm{~mL}$ $\mathrm{min}^{-1}$; oven temperature program was $60-250{ }^{\circ} \mathrm{C}$ at the rate of $4{ }^{\circ} \mathrm{C} \min ^{-1}$ and finally held isothermally for $10 \mathrm{~min}$, and split ratio was $1: 50$.

\section{Gas chromatography- mass spectrometry analysis}

The chemical characterization of the essential oil was performed by a ThermoquestFinnigan gas chromatography, Model 2000, USA, coupled with Trace mass spectrometry, UK. The temperature program conditions and the column characteristics were the same as those employed and described for GC. Temperature of the transfer line was kept to $250{ }^{\circ} \mathrm{C}$. The carrier gas (helium) was used at a constant and linear flow rate of $1.1 \mathrm{~mL} \mathrm{~min}^{-1}$. Also, FID split ratio was equal to 1:50. Mass spectra were obtained over the range of 35-465 a.m.u. (atomic mass units) in the electron ionization mode with a voltage of $70 \mathrm{eV}$.

\section{Identification of essential oil constituents}

The constituents of the EO were identified by calculating their retention indices under temperature-programmed conditions for $n$ alkanes $\left(\mathrm{C}_{6}-\mathrm{C}_{24}\right)$ and the oil on a DB-5 column under the same chromatographic conditions. Identification of individual compounds was made by comparing their mass spectra with those of the internal reference mass spectra library (Adams and Wiley 7.0) or with authentic compounds and confirmed by comparing their retention indices with authentic compounds or 
with those of reported in the literature [21]. For quantification purpose, relative area percentages obtained by FID were used without the use of correction factors.

\section{Chemical analysis of soil and sewage sludge}

The soil sample was taken from the surface down to $25 \mathrm{~cm}$ depth at the Research Farm of Nuclear Agriculture Research School, located in the Ramandeh village in Savojbolagh ( $35^{\circ} 49^{\prime}$ $26^{\prime \prime} \mathrm{N}, 50^{\circ} 44^{\prime} 38^{\prime \prime}$ E), Alborz Province, Iran. After air drying, crushing and passing through a $2 \mathrm{~mm}$ sieve, some physicochemical properties of the soil as well as SSGI and SSNI were measured (Tables 1 and 2, respectively). The chemical characteristics of SSGI and SSNI such as total concentrations of some nutrients and HMs including phosphorus (P) (measured by vanado-molybdate yellow method), potassium $(\mathrm{K})$, sodium $(\mathrm{Na})$, calcium $(\mathrm{Ca})$, magnesium $(\mathrm{Mg})$, copper $(\mathrm{Cu})$, zinc $(\mathrm{Zn})$, manganese $(\mathrm{Mn})$, lead $(\mathrm{Pb})$, cadmium $(\mathrm{Cd})$, iron $(\mathrm{Fe})$ and nickel $(\mathrm{Ni})$ were determined by dry ashing the SS and the ash treatment with diacid mixture [hydrochloric acid $(\mathrm{HCl})+$ nitric acid $\left(\mathrm{HNO}_{3}\right)$ in 3:1 ratio] according to Westerman [22]. Also, the concentrations of
$\mathrm{Cu}, \mathrm{Zn}, \mathrm{Mn}, \mathrm{Ni}, \mathrm{Fe}, \mathrm{Pb}$ and $\mathrm{Cd}$ in plant shoot and root were measured as mentioned above method for SS. Additional chemical properties of the SSGI and SSNI including electrical conductivity (EC) and $\mathrm{pH}$ (1: 5 sludge to water ratio) and total Kjeldahl nitrogen (TKN) were analyzed using standard methods [23].

Also, some physical and chemical properties of the soil sample such as available-P were measured by Olsen method, total nitrogen by Kjeldahl method, available-K by $1 \mathrm{~N}$ acetate ammonium, available- $\mathrm{Cu}, \mathrm{Zn}, \mathrm{Fe}$, and $\mathrm{Mn}$ by DTPA-TEA, EC and $\mathrm{pH}$ in saturated extract, cation exchange capacity (CEC) by Bower method, soil texture by hydrometric method and organic carbon (OC) by the wet oxidation method were measured $[25,26]$. Overall, the concentrations of $\mathrm{Ca}, \mathrm{Mg}, \mathrm{Cu}, \mathrm{Zn}, \mathrm{Pb}, \mathrm{Cd}, \mathrm{Fe}$, $\mathrm{Mn}$, and $\mathrm{Ni}$ in extracts were analyzed using atomic absorption spectrophotometer (Shimadzu model AA-6300, Japan), Na and K by flame photometer (Corning-410, UK), pH by $\mathrm{pH}$ meter (Mettler Toledo Instrument Co. Ltd., MA235, USA), EC by JENWAY EC meter (model 4320, UK), and P by SU6100 spectrophotometer (Philler Scientific, USA).

Table 1- General physicochemical properties of the studied soil

\begin{tabular}{cccc}
\hline Characteristic & Quantity & Characteristic & Quantity \\
\hline Soil texture & Sandy clay loam & CEC $\left(\mathrm{cmol}_{\mathrm{c}} \mathrm{kg}^{-1}\right)$ & 11.7 \\
Soil taxonomy & Typic Haploxerepts & Total N $\left(\mathrm{mg} \mathrm{kg}^{-1}\right)$ & 350 \\
Clay (\%) & 28.3 & Available-P $\left(\mathrm{mg} \mathrm{kg}^{-1}\right)$ & 3.4 \\
Silt $(\%)$ & 18 & Available-K $\left(\mathrm{mg} \mathrm{kg}^{-1}\right)$ & 261 \\
Sand $(\%)$ & 53.7 & Available-Fe $\left(\mathrm{mg} \mathrm{kg}^{-1}\right)$ & 12.3 \\
pH & 7.18 & Available-Mn $\left(\mathrm{mg} \mathrm{kg}^{-1}\right)$ & 2.8 \\
$\left.\mathrm{EC}_{\mathrm{e}}(\mathrm{dS} \mathrm{m})^{-1}\right)$ & 0.98 & Available-Cu $\left(\mathrm{mg} \mathrm{kg}^{-1}\right)$ & 0.8 \\
$\mathrm{CaCO}_{3}(\%)$ & 6.53 & Available-Zn $\left(\mathrm{mg} \mathrm{kg}^{-1}\right)$ & 0.45 \\
$\mathrm{OC}(\%)$ & 0.37 & Available-Cd $\left(\mathrm{mg} \mathrm{kg}^{-1}\right)$ & 0.22 \\
$\mathrm{FC}(\%)$ & 18.1 & & \\
\hline
\end{tabular}


Table 2-Changes in chemical characteristics of the sewage sludge following gamma irradiation

\begin{tabular}{|c|c|c|c|c|c|}
\hline \multirow{2}{*}{ Characteristics } & \multicolumn{4}{|c|}{ Absorbed dose (kGy) } & \multirow[t]{2}{*}{ limit value ${ }^{*}$} \\
\hline & $\mathbf{0}$ & 5 & 10 & 20 & \\
\hline $\mathrm{Ni}\left(\mathrm{mg} \mathrm{kg}^{-1}\right)$ & $36.8 \pm 0.75 a$ & $36.35 \pm 0.2 \mathrm{a}$ & $35 \pm 1.1 \mathrm{a}$ & $34.8 \pm 1.6 \mathrm{a}$ & 420 \\
\hline $\mathrm{Zn}\left(\mathrm{mg} \mathrm{kg}^{-1}\right)$ & $1495 \pm 3.8 \mathrm{a}$ & $1491 \pm 7.9 a$ & $1483 \pm 4.4 \mathrm{a}$ & $1472 \pm 13.1 \mathrm{a}$ & 7500 \\
\hline $\mathrm{Cu}\left(\mathrm{mg} \mathrm{kg}^{-1}\right)$ & $164.2 \pm 1 \mathrm{a}$ & $161.8 \pm 1.1 \mathrm{ab}$ & $157.3 \pm 1.95 b c$ & $154.7 \pm 2.7 \mathrm{c}$ & 4300 \\
\hline $\mathrm{Pb}\left(\mathrm{mg} \mathrm{kg}^{-1}\right)$ & $117.3 \pm 1.3 \mathrm{a}$ & $115.4 \pm 1.8 \mathrm{a}$ & $111.3 \pm 3.3 \mathrm{a}$ & $108.9 \pm 6.3 \mathrm{a}$ & 840 \\
\hline $\mathrm{Cd}\left(\mathrm{mg} \mathrm{kg}^{-1}\right)$ & $3.03 \pm 0.18 \mathrm{a}$ & $2.76 \pm 0.11 \mathrm{a}$ & $2.68 \pm 0.13 \mathrm{a}$ & $2.62 \pm 0.12 \mathrm{a}$ & 85 \\
\hline $\mathrm{Fe}(\mathrm{mg} \mathrm{kg}-1)$ & $5750 \pm 14.4 a$ & $5725 \pm 28.9 a$ & $5683 \pm 74.1 \mathrm{a}$ & $5583 \pm 58.3 a$ & \\
\hline $\operatorname{Mn}\left(\mathrm{mg} \mathrm{kg}^{-1}\right)$ & $149 \pm 2.1 \mathrm{a}$ & $149.6 \pm 0.16 a$ & $145.2 \pm 2.85 a$ & $145.8 \pm 2.2 \mathrm{a}$ & \\
\hline $\operatorname{Mg}\left(\mathrm{mg} \mathrm{g}^{-1}\right)$ & $4.5 \pm 0.12 \mathrm{a}$ & $4.6 \pm 0.13 a$ & $4.6 \pm 0.26 \mathrm{a}$ & $4.4 \pm 0.22 \mathrm{a}$ & \\
\hline $\mathrm{Ca}\left(\mathrm{mg} \mathrm{g}^{-1}\right)$ & $33.9 \pm 0.8 \mathrm{a}$ & $34.2 \pm 2.2 \mathrm{a}$ & $37.8 \pm 1.6 \mathrm{a}$ & $37.2 \pm 1.4 \mathrm{a}$ & \\
\hline $\mathrm{Na}\left(\mathrm{mg} \mathrm{g}^{-1}\right)$ & $1.13 \pm 0.08 \mathrm{a}$ & $1.03 \pm 0.06 \mathrm{a}$ & $1.10 \pm 0.05 a$ & $1.16 \pm 0.06 \mathrm{a}$ & \\
\hline $\mathrm{K}\left(\mathrm{mg} \mathrm{g}^{-1}\right)$ & $2.03 \pm 0.06 a$ & $2.07 \pm 0.08 \mathrm{a}$ & $1.90 \pm 0.11 \mathrm{a}$ & $1.90 \pm 0.11 \mathrm{a}$ & \\
\hline $\mathrm{P}\left(\mathrm{mg} \mathrm{g}^{-1}\right)$ & $2.42 \pm 0.01 \mathrm{a}$ & $2.53 \pm 0.04 a$ & $2.45 \pm 0.02 \mathrm{a}$ & $2.51 \pm 0.05 a$ & \\
\hline $\mathrm{N}\left(\mathrm{mg} \mathrm{g}^{-1}\right)$ & $26.7 \pm 0.98 b$ & $28.7 \pm 0.49 \mathrm{ab}$ & $30.6 \pm 1.65 \mathrm{ab}$ & $31 \pm 1.59 \mathrm{a}$ & \\
\hline $\mathrm{pH}(1: 5)$ & $6.91 \pm 0.02 \mathrm{a}$ & $6.75 \pm 0.06 a b$ & $6.68 \pm 0.08 \mathrm{ab}$ & $6.61 \pm 0.12 b$ & \\
\hline $\operatorname{EC~}(1: 5)\left(\mathrm{dS} \mathrm{m} \mathrm{m}^{-1}\right)$ & $2.97 \pm 0.04 \mathrm{a}$ & $2.75 \pm 0.12 \mathrm{ab}$ & $2.7 \pm 0.08 \mathrm{ab}$ & $2.62 \pm 0.12 b$ & \\
\hline
\end{tabular}

Different letters in each row show significant difference at $\mathrm{p} \leq 0.05$ by Duncan multiple range test.

*USEPA standard for biosolid applied to land [24]

\section{Statistical analysis}

All data were processed based on a completely randomized design with three replications. Statistical analyses including analysis of variance and means comparison by Duncan's multiple range test $(\mathrm{p}<0.05)$ were performed by SAS software (computer SAS software version 9.1; CoHort Software). Values were expressed as mean \pm standard error (SE). The Excel software (Excel software 2013, Microsoft Inc., WA, USA) was used to draw the figures.

\section{Results}

\section{Effects of SSGI and SSNI applications on essential oil content and yield}

The data pertaining to essential oil (EO) yield and content of sweet basil were presented in Figures 1a and b. The EO content under all SSGI and SSNI applications treatments except $\mathrm{SS}_{15} \mathrm{NI}, \mathrm{SS}_{15} \mathrm{GI}_{5}, \mathrm{SS}_{15} \mathrm{GI}_{10}$ and $\mathrm{SS}_{15} \mathrm{GI}_{20}$ was significantly increased as compared to the control $(p<0.05)$, albeit even no significant differences were found between the other treatments $\quad\left(\mathrm{SS}_{30} \mathrm{NI}, \quad \mathrm{SS}_{30} \mathrm{GI}_{5}, \quad \mathrm{SS}_{30} \mathrm{GI}_{10}\right.$, $\mathrm{SS}_{30} \mathrm{GI}_{20}, \quad \mathrm{SS}_{60} \mathrm{NI}, \quad \mathrm{SS}_{60} \mathrm{GI}_{5}, \quad \mathrm{SS}_{60} \mathrm{GI}_{10}, \quad$ and $\mathrm{SS}_{60} \mathrm{GI}_{20}$ ) (p> 0.05). The EO yield was significantly promoted and/or restricted under the treatments applications compared to the control. So that, application of $60 \mathrm{~g} \mathrm{SS}$ per $\mathrm{kg}$ soil in each absorbed dose of gamma-ray $\left(\mathrm{SS}_{60} \mathrm{NI}, \quad \mathrm{SS}_{60} \mathrm{GI}_{5}, \quad \mathrm{SS}_{60} \mathrm{GI}_{10}\right.$, and $\mathrm{SS}_{60} \mathrm{GI}_{20}$ treatments) significantly reduced EO yield relative to the control $(\mathrm{p}<0.05)$, while it was significantly increased in the other treatments ( $p<0.05)$, although no significant differences were found between SS levels with different absorbed doses except $\mathrm{SS}_{30} \mathrm{NI}$ as compared with $\mathrm{SS}_{30} \mathrm{GI}_{5}$, and $\mathrm{SS}_{30} \mathrm{GI}_{10}$ as well as $\mathrm{SS}_{30} \mathrm{GI}_{20}$ and $\mathrm{SS}_{60} \mathrm{NI}$ as compared with $\mathrm{SS}_{60} \mathrm{GI}_{5}, \mathrm{SS}_{60} \mathrm{GI}_{10}$, and $\mathrm{SS}_{60} \mathrm{GI}_{20}$ treatments. However, the 

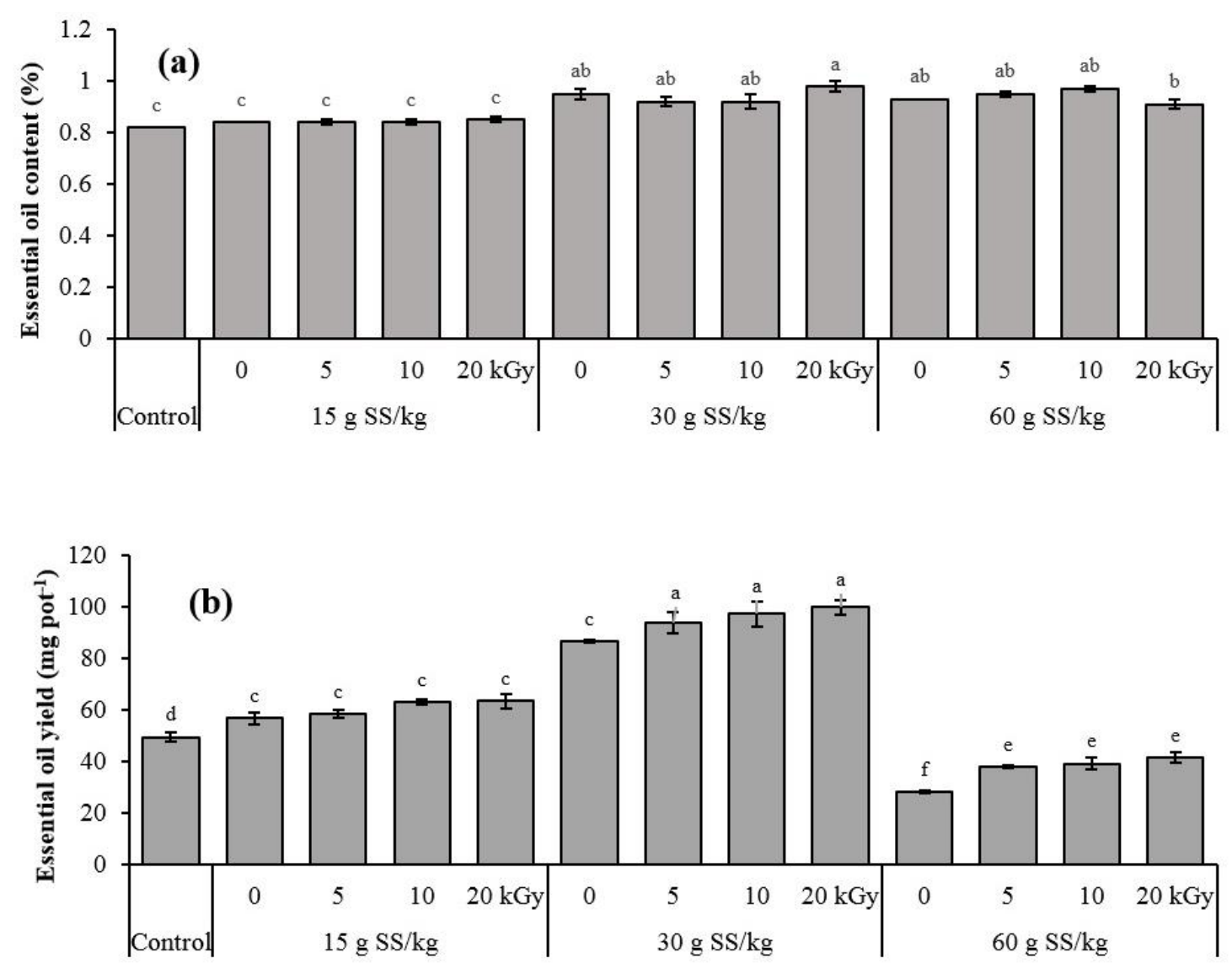

Fig. 1- Essential oil content (a) and yield (b) of Ocimum basilicum L. under different levels of gamma irradiated and non-irradiated sewage sludge

maximum EO content and yield were observed in $\mathrm{SS}_{30} \mathrm{GI}_{20}$, which had 21 and $102 \%$ increase over the respective control, respectively.

\section{Effects of SSGI and SSNI applications on essential oil constituents}

The extracted EO was submitted to GC-MS analysis (Fig. 2). Also, sample chromatograms of GC-FID of EO isolated from aerial parts of $O$. basilicum in some treatments were presented in the Fig. 3. The chemical composition of EO of sweet basil under different treatments was listed in the Table 3. Twenty-one constituents according to $98.35-99.89 \%$ of the total oil, with the methyl chavicol as the major component were identified for EO of all treatments.
However, methyl chavicol as dominant components ranging from 92.54 to $96.68 \%$ for all 13 treatments tested. Methyl chavicol content for all treatments was significantly higher than the control treatment $(\mathrm{p}<0.05)$, and the lowest and the highest of its contents occurred in the control and $\mathrm{SS}_{60} \mathrm{GI}_{20}$ treatments. Although, no significant differences existed between $\mathrm{SS}_{15} \mathrm{GI}_{10}, \mathrm{SS}_{15} \mathrm{GI}_{20}, \mathrm{SS}_{30} \mathrm{NI}, \mathrm{SS}_{30} \mathrm{GI}_{5}$, $\mathrm{SS}_{30} \mathrm{GI}_{10}, \mathrm{SS}_{30} \mathrm{GI}_{20}, \mathrm{SS}_{60} \mathrm{NI}, \mathrm{SS}_{60} \mathrm{GI}_{5}, \mathrm{SS}_{60} \mathrm{GI}_{10}$, $\mathrm{SS}_{60} \mathrm{GI}_{20} \quad$ ( $\mathrm{p}>$ 0.05). Therefore, $\mathrm{SS}_{60} \mathrm{GI}_{20}$ showed the best performance in terms of the increase in Methyl chavicol content, which was higher than that of other treatments and was $4.47 \%$ greater than that in the control treatment. On the other hand, as indicated in the Table 3 , 
the other components were negligible and were less than $7 \%$ of total in different treatments. So, due to the negligible portion of other components, further discussion was done about the results of methyl chavicol in the following. Classification of the identified compounds based on functional groups was summarized in the Table 3. As seen, a small fraction of essential oils was devoted to various groups of terpenes including oxygenate monoterpenes, hydrocarbonate monoterpenes, oxygenate sesquiterpenes and hydrocarbonate sesquiterpenes (1.88 to $5.59 \%$ ). So that, the maximum amounts of terpenes compounds were recorded in the control treatment and their amounts were decreased with the application of gamma irradiated and non-irradiated sewage sludge. Therefore, the major part of essential oils related to phenylpropanoids was categorized as "other" group. The application of gamma irradiated and non-irradiated sewage sludge increased the amount of phenylpropanoids compounds.

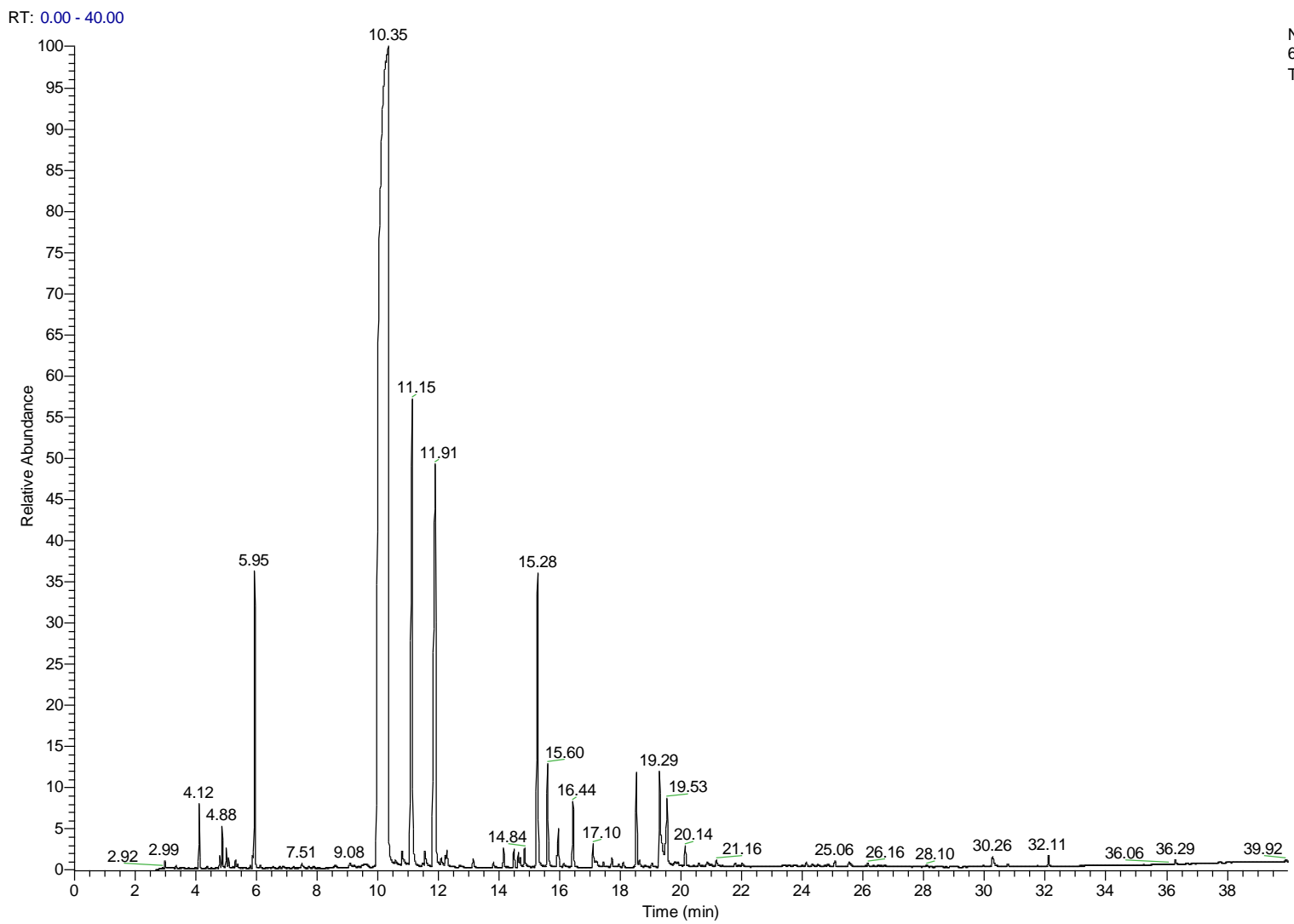

Fig. 2- The GC-MS chromatogram of the chemical composition of the essential oil from Ocimum basilicum L. aerial parts 
Asgari Lajayer et al.

(A)

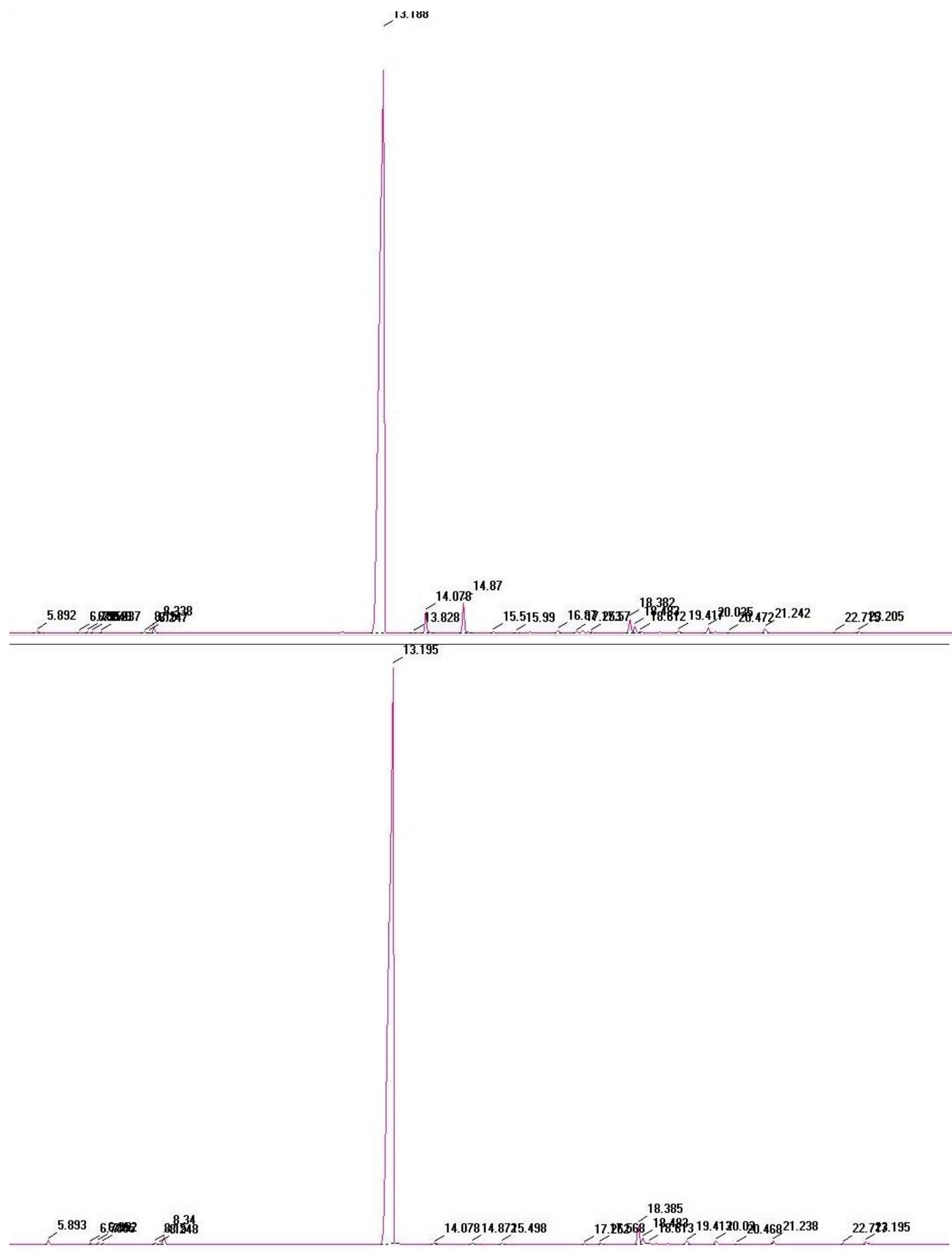

(B) 
Effects of Gamma ...

(C)

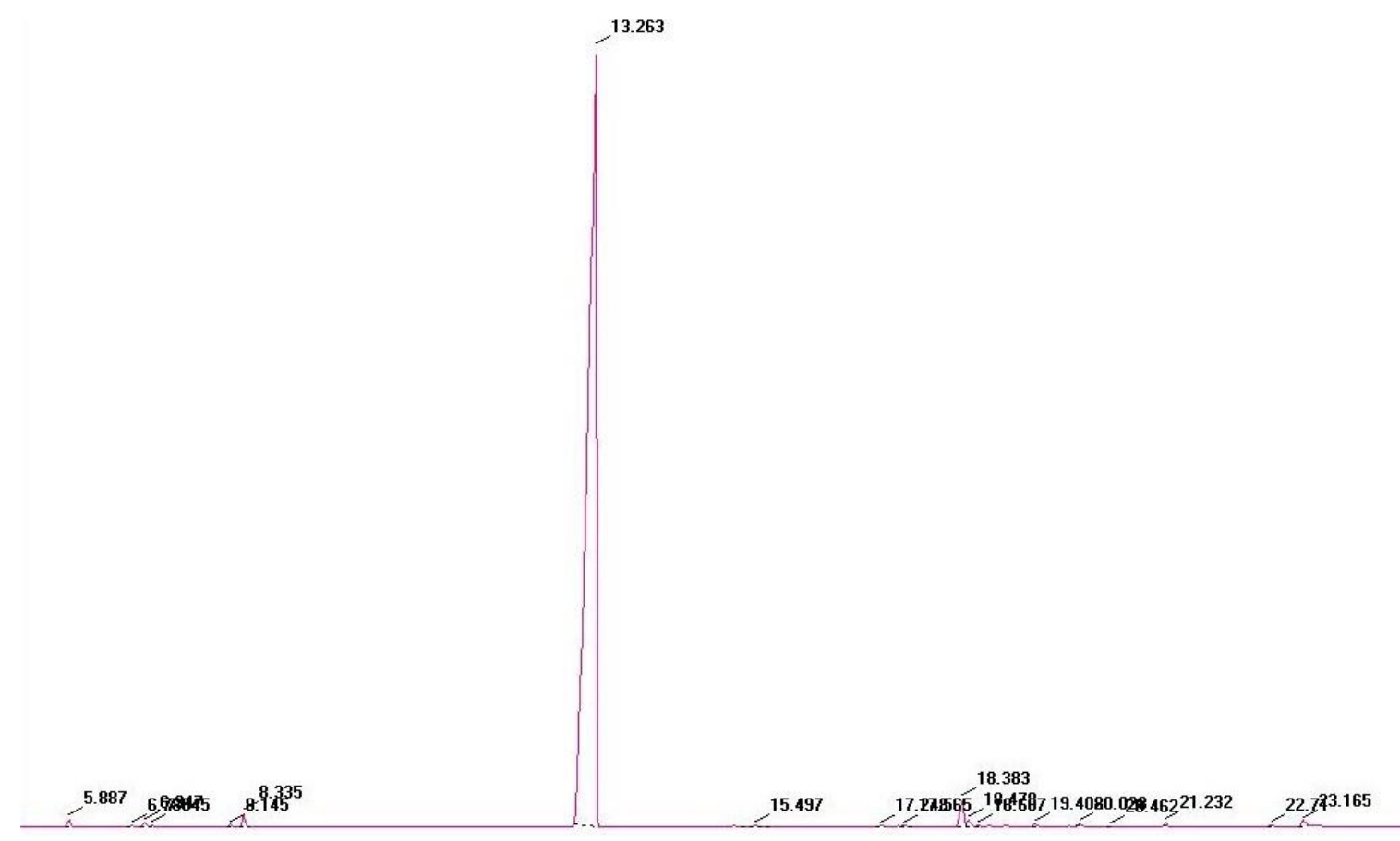

(D)

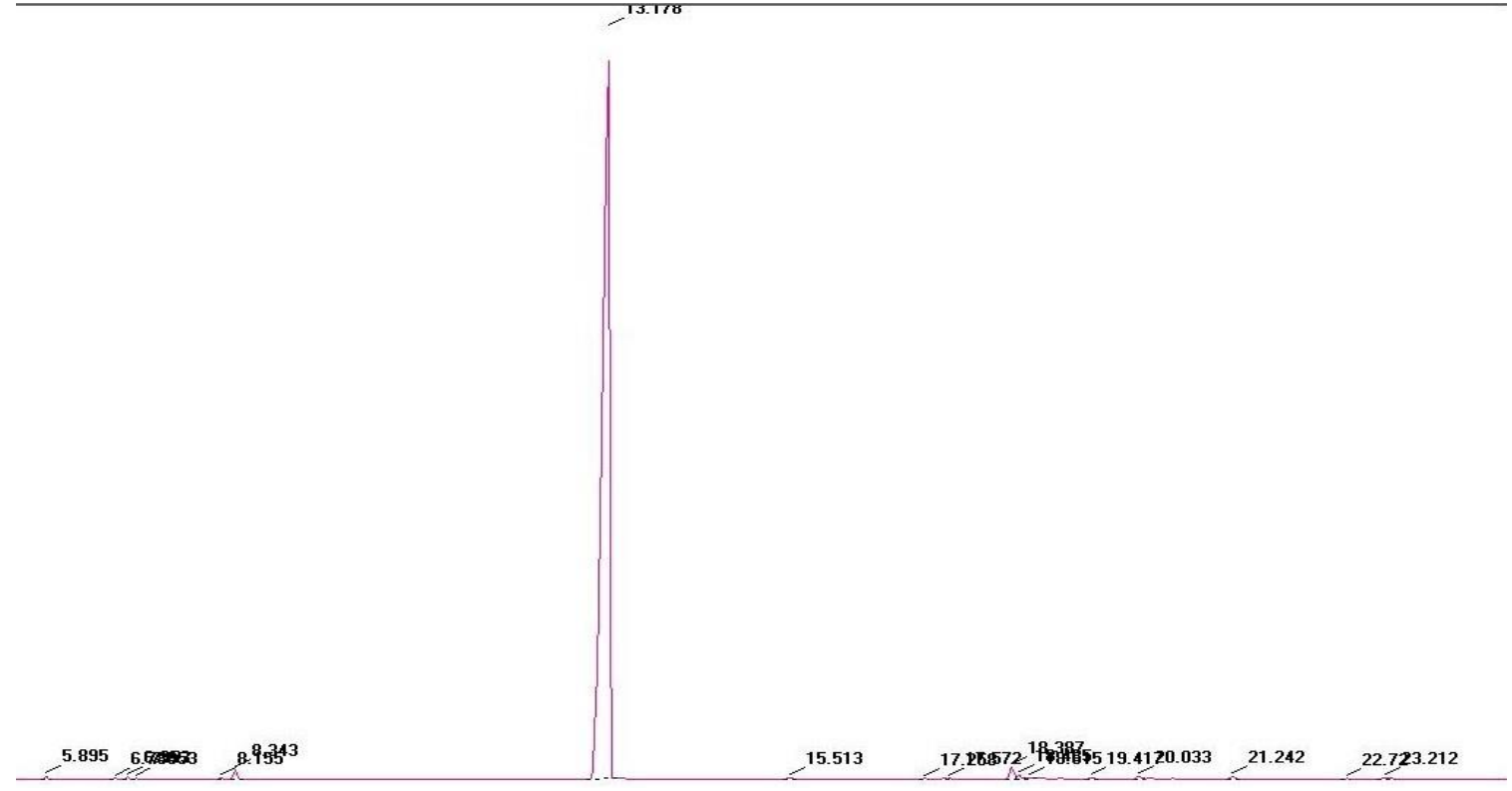

Fig. 3- Sample chromatograms of GC-FID of essential oil isolated from Ocimum basilicum L. aerial parts in treatments of (A): Control as soil without sewage sludge and irradiation; (B): $15 \mathrm{~g} \mathrm{~kg}^{-1}$ of sewage sludge irradiated with $20 \mathrm{kGy}$; (C): $30 \mathrm{~g} \mathrm{~kg}^{-1}$ of sewage sludge irradiated with $20 \mathrm{kGy}$; (D): $60 \mathrm{~g} \mathrm{~kg}^{-1}$ of sewage sludge irradiated with $20 \mathrm{kGy}$ 


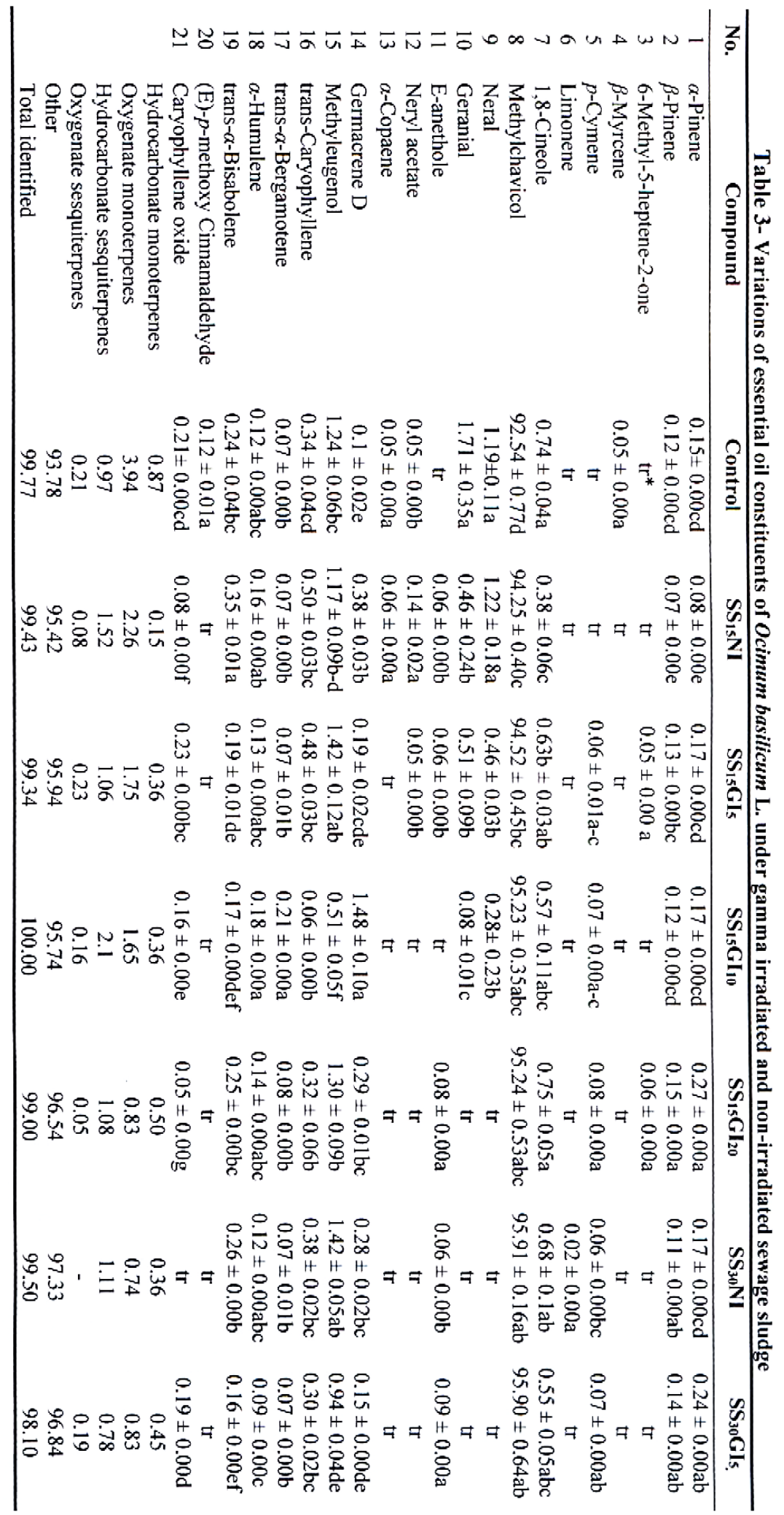


Effects of Gamma ...

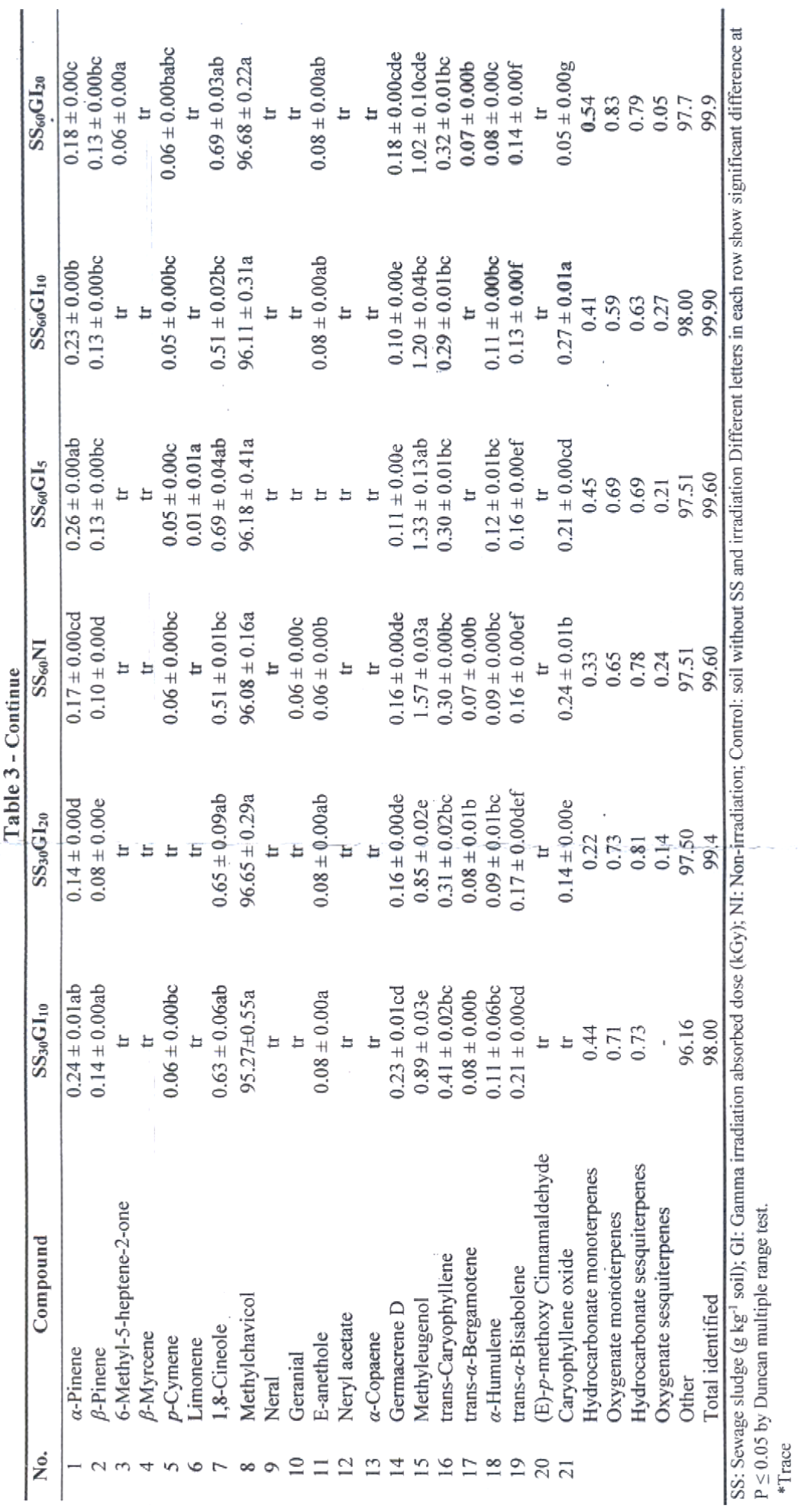

110 Journal of Medicinal Plants, Volume 18,
No. 71, Summer 2019 


\section{Discussion}

It can be concluded that essential oil (EO) of basil was mainly composed of terpenes/terpenoids constituents and originated from two distinct biosynthetic pathways including shikmic and mevalonic pathways. The shikmic pathway is mediated by the activity of phenylalanine ammonia-lyase (PAL) and leads to accumulation of phenolic compounds while mevalonic pathway is connected with photosynthesis, $\mathrm{CO}_{2}$ fixation, glucose production, as well as terpenoid biosynthesis [27]. In other words, the biosynthetic EO requires adenosine triphosphate (ATP) and nicotinamide adenine dinucleotide phosphate (NADPH) [18]. Thus, organic material containing macro- and micronutrients and due to created more favorable conditions for better plant growth [17], nutrient uptake [7], and consequently supplying source of carbon utilized in terpene, biosynthesis pathway may positively effect on EO quantity [14]. The results have been supported by various researchers such as Bajeli et al. [17]. They reported that the increase in EO content can be attributed to the effect of organic materials including farmyard manure, poultry manure and vermicompost on the dilution of EO concentration in the leaves. Hussein et al. [28] reported that organic manures such as compost increase the EO content due to the effect of compost on accelerating metabolism reactions as well as stimulating enzymes. On the other hand, it has been reported that accumulation of secondary metabolites could be occurred in medicinal and aromatic plants in response to different types of stresses [13, 29, 30]. In other words, the stress of heavy metals
(HMs) induced biosynthesis pathway (elicitation) and caused production of secondary metabolites through stimulation of immune responses in medicinal plant [13]. Thus, the sewage sludge (SS) contains coexisting of nutrients and excessive amounts of HMs (Table 2), which consequently causes elicitation of EO content as mentioned above. Also, the increase in EO yield in treatment mentioned above could be due to the effects of gamma irradiated and non-irradiated sewage sludge (SSGI and SSNI) on biomass production and/or oil content. Other researchers previously reported the positive role of organic matter on the improvement of EO yield of medicinal plants [15, 16, 18, 28, 31]. Najafi et al. [32], Mahmoudi et al. [33] and Chu et al. [7] reported that several physicochemical and biological soil properties such as $\mathrm{pH}$, bulk density, porosity, water-holding capacity, and supplying nutrients showed improvement because of the SS addition and its positive influence on soil properties generally resulted in a positive effect on the growth and nutrient uptake by plants. Similarly, Mohamed et al. [34] suggested that improved shoot yield of Moroccan sunflower may be attributed to potential source of nitrogen and phosphorus for plants in SS treatments. Furthermore, excess amounts of SS reported to have adverse effects on different parameters such as biomass production [7, 354], and balance of macro- and micronutrients levels $[36,37]$. Overall, the positive effects of SSGI and SSNI at lower and/or moderate levels (15 and $30 \mathrm{~g} \mathrm{~kg}^{-1}$ ) and the negative effect at high levels of SS $\left(60 \mathrm{~g} \mathrm{~kg}^{-1}\right)$ on EO yield is possibly a consequence of the positive and negative effects of SS on plant growth and/or essential

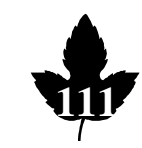


oil content in different levels of SS.

In the case of the effects of SSGI and SSNI applications on essential oil constituents, it could be concluded that applications of SSGI and SSNI did not alter the trend of chemotype as compared to the control. Many reports on the chemical composition and chemotype of EO of sweet basil plants have been published previously [11, 38-40]. However, our findings were in agreement with those of Kasali et al. [41], Ghanati et al. [27], and Kumar et al. [42] who noted that methyl chavicol was the dominate constituent. On the other hand, it is well known that there are various classifications for chemotypes of basil oils according to their major compounds, including (1) methyl chavicol-rich, (2) linalool-rich, (3) methyleugenol-rich, (4) methyl cinnamate-rich, and also numerous subtypes [39]. For this reason, the sample of basil plants in all treatments showed high content of methyl chavicol which could be grouped into methyl chavicol chemotype.

It is well known that elicitation of secondary metabolites often occurs in plants subjected to different types of stresses and is regulated by the several factors including genetic and evolution, growing conditions, physiological variations, climate, photoperiod, temperature, light, agronomic factors such as soil amendments, mineral elements (such as $\mathrm{N}, \mathrm{P}$, $\mathrm{K}, \mathrm{Ca}, \mathrm{Cu}, \mathrm{Zn}$, and $\mathrm{Fe}$ ), and trace elements (including $\mathrm{Pb}, \mathrm{Cd}, \mathrm{Cr}$, and $\mathrm{Ni}$ ) [13, 14, 43, 44]. However, little information is available about the effect of SSGI on quality of secondary metabolites biosynthesis in medicinal plants especially in basil. It has been reported that application of SS irradiated with $6 \mathrm{kGy}$ absorbed dose of gamma-ray in a sandy soil caused an increase in Fenchone content as one of the major constituents of fennel plant EO, while t-anethole was relatively higher in plants grown under SSNI [4]. Patel and Patra [31] reported that the major constituents of Tagetes minuta oil such as limonene, Cis-ocimene, Ztagetone and E-tagetone were found to be maximum in 50:50 combinations of both studied soils with tannery sludge. So that, even 100:0 combination of tannery sludge and soil (full sludge and no soil) had no adverse effect on amount of mentioned constituent. Nutritional treatment $(\mathrm{Cu}$ and $\mathrm{Zn})$ had a significant effect on linalool and methyl chavicol as major EO constituent of basil in comparison to control plants [11]. On the contrary, Bolechowski et al. [45] reported that mixing organic material (different composts such as citrus juice waste, tomato soup waste and cattle manure in combining with exhausted grape marc) with perlite and peat at different levels decreased major constituent of Thymus vulgaris including $p$-cymene and thymol. Totally, relative increase of major compounds of basil EO in plants cultivated on SSGI and/or SSNI treated soil suggested that treatment of medicinal plants such as basil with SSGI and/or SSNI can be introduced as a tool in order to produce more desired medicinal compounds.

On the other hand, one positive point in medicinal and aromatic plants is that in the process of EO extraction by distillation, there is very less probability of heavy metals being present in the oil and metal-free extracted oils could be safely marketed [13]. Several authors have reported effects of HMs on changes of chemical composition of EO in medicinal 
plants [14, 29, 40]. Even though, some studies have been done on sole application of organic matter including compost on altering chemical composition of sweet basil. For example, Zheljazkov and Warman [46] reported that additions of municipal solid waste compost with concentrations of $\mathrm{Cu} 311 \mathrm{mg} \mathrm{kg}^{-1}, \mathrm{~Pb} 223$ $\mathrm{mg} \mathrm{kg}^{-1}$, Mo $17 \mathrm{mg} \mathrm{kg}^{-1}$, and $\mathrm{Zn} 767 \mathrm{mg} \mathrm{kg}^{-1}$ to soil altered the chemical composition of basil oil, but the basil oil obtained from crops grown on enriched medium would be easily marketable. But, the literature review showed that no study has been carried out on the comparison of SSGI and SSNI effects on chemical composition of volatile oil of sweet basil. However, the observed modification in the synthesis of some EO constituents in treated plants considered as a defense response to metal stresses of SSNI and SSGI. So that, methyl chavicol as dominant constituent of EO of basil have known antioxidant properties [47], which may play a role in the defense mechanisms of sweet basil against heavy metal contents of SSGI and SSNI as antioxidant compounds.

The changes in classification of the identified compounds with SSGI and SSNI applications could be mentioned that essential oils are originated from two distinct biosynthetic pathways: shikmic pathway and mevalonic pathway. Shikmic pathway is mediated by the activity of phenylalanine ammonia-lyase (PAL) enzyme and leads to production of phenolic compounds while mevalonic pathway is connected with photosynthesis, assimilation, and growth and results in production of terpenoides. They are although produced by the Methylerythritol phosphate [27]. The expression and activity of
PAL enzyme has a direct correlation with the amount of phenylpropanoids, and by decreasing its activity, the amount of phenylpropanoids is also reduced [48]. The factors affecting the expression of PAL enzyme and subsequently the production of phenylpropanoids compounds in plants including plant age, concentration of growth regulators, various abiotic stresses such as herbicides, temperature, macro- and micronutrients and heavy metals contents, and microbial contaminations such as viral, bacterial and fungal [49]. Wen et al. [50] reported that increasing the expression of PAL enzyme and consequently increasing the content of phenolic compounds caused induction of the plant's resistance to stress. In other words, it can be stated that stimulating the production of these compounds may have been achieved by inducing the systematic resistance of the plant to external agents. Systematic resistance stimulation increases plant cell wall resistance, changes plant physiologic and metabolic responses, and increases the production of defense chemicals in abioticstress conditions [51]. However, the altering essential oil composition biosynthesis of basil such as phenylpropanoids and terpenoses probably could be due to the bioenergetic changes in the plant cells in response to the treatments.

\section{Conclusion}

Sewage sludge improved essential oil content and yield of basil as well as chemical constituent of essential oil. When, soil received gamma irradiated and non-irradiated sewage sludge in the rate of $60 \mathrm{~g} \mathrm{~kg}^{-1}$, essential oil yield 
significantly reduced relative to other treatments. Applications of gamma irradiated and non-irradiated sewage sludge even at the highest level (60 $\mathrm{g} \mathrm{kg}^{-1}$ soil), not only had no negative effect on basil essential oil content, but also increased it as compared to the control. Thus, the decrease in essential oil yield is possibly a consequence of the negative effect of sewage sludge on plant growth because of increasing soil solution salinity. In total, 21 constituents were identified that representing about $98.35-99.89 \%$ of the essential oil compositions. The methyl chavicol as the major component of $O$. basilicum essential oil was significantly improved by the applications of gamma irradiated and non-irradiated sewage sludge as compared with the control. The best performance in terms of methyl chavicol content was obtained by the application of $60 \mathrm{~g}$ gamma irradiated sewage sludge per $\mathrm{kg}$ soil. However, the enhanced methyl chavicol content was not significant between the treatments of $\geq 30 \mathrm{~g} \mathrm{~kg}^{-1}$ gamma irradiated or non-irradiated sewage sludge and $15 \mathrm{~g} \mathrm{~kg}^{-1}$ sewage sludge at absorbed dose of $\geq 10 \mathrm{kGy}$. With considering a significant improvement of essential oil content and composition and costeffective application of gamma-ray, it may be concluded that the application of $\leq 30 \mathrm{~g}$ sewage sludge per $\mathrm{kg}$ soil with $5 \mathrm{kGy}$ absorbed dose of gamma-ray can be suggested as practical recommendation under similar conditions.

\section{References}

1. Asgari Lajayer B, Najafi N, Moghiseh E, Mosaferi $\mathrm{M}$ and Hadian J. Micronutrient and heavy metal concentrations in basil plant cultivated on irradiated and non-irradiated sewage sludge- treated soil and evaluation of human health risk. Regulatory Toxicology and Pharmacology 2019; 104: 141-50.

2. Fytili D and Zabaniotou A. Utilization of sewage sludge in EU application of old and new methods-a review. Renewable and Sustainable Energy Reviews 2008; 12: 116-40. 3. Manara P, Zabaniotou A. Towards sewage sludge based biofuels via thermochemical conversion - A review. Renewable and Sustainable Energy Reviews 2012; 16: 2566-82.

4. El-Motaium $\mathrm{R}$ and El-Seoud MA. Irradiated sewage sludge for production of fennel plants in sandy soil. Nutrient Cycling in Agroecosystems 2007; 78: 133-42.

5. Ahmed AU and Sorensen DL. Autoheating and pathogen destruction during storage of dewatered biosolids with minimal mixing. Water Environment Res. 1997; 69: 81-94.

6. Rathod PH, Patel JC, Shah MR and Jhala AJ. Recycling gamma irradiated sewage sludge as fertilizer: A case study using onion (Alium cepa). Applied Soil Ecol. 2009; 41: 223-33.

7. Chu S, Wu D, Liang LL, Zhong F, Hu Y, $\mathrm{Hu}$ X, Lai C and Zeng S. Municipal sewage sludge compost promotes Mangifera persiciforma tree growth with no risk of heavy metal contamination of soil. Scientific Reports 2017; 7: 13408.

8. Turovskiy IS and Mathai P. Wastewater sludge processing: John Wiley \& Sons. 2006, p: 354.

9. Gautam S, Shah MR, Sabharwal S, Sharma A, Gamma irradiation of municipal sludge for safe disposal and agricultural use. Water Environment Res. 2005; 77: 472-9.

10. IAEA, Irradiated sewage sludge for application to cropland. Results of a co- 
Asgari Lajayer et al.

ordinated research project. (Joint FAO/IAEA Division of Nuclear Techniques in Food and Agriculture), International Atomic Energy Agency, Vienna (Austria). 2002, p: 238.

11. Ghorbanpour $M$, Asgari Lajayer $H$ and Hadian J. Influence of copper and zinc on growth, metal accumulation and chemical composition of essential oils in sweet basil (Ocimum basilicum L.). JMP. 2016; 3: 132-44.

12. Song $U$ and Lee EJ. Environmental and economical assessment of sewage sludge compost application on soil and plants in a landfll. Resources, Conservation and Recycling. 2010; 54, 1109-16.

13. Asgari Lajayer B, Ghorbanpour $M$ and Nikabadi S. Heavy metals in contaminated environment: Destiny of secondary metabolite biosynthesis, oxidative status and phytoextraction in medicinal plants. Ecotoxicology and Environmental Safety 2017 a; 145: 377-90.

14. Asgari Lajayer H, Savaghebi GR, Hadian J, Hatami M and Pezhmanmehr M. Comparison of copper and zinc effects on growth, micro-and macronutrients status and essential oil constituents in pennyroyal (Mentha pulegium L.). Brazilian Journal of Botany. 2017 b; 40: 379-88.

15. Chattopadhyay A, Prasad A, Singh K and Chand S. Influence of Gypsum and Farmyard Manure Application in Soil on Yield and Chemical Composition of Essential oil of Rose Scented Geranium (Pelargonium graveolens L'Herit. ex Ait.). Journal of Essential Oil Bearing Plant. 2015; 18: 1353-9.

16. Moghaddam M, Estaji A, Farhadi N. Effect of organic and inorganic fertilizers on morphological and physiological characteristics, essential oil content and constituents of agastache (Agastache foeniculum). J. Essential Oil Bearing Plant. 2015; 18: 1372-81.

17. Bajeli J, Tripathi S, Kumar A, Tripathi A and Upadhyay R. Organic manures a convincing source for quality production of Japanese mint (Mentha arvensis L.). Industrial Crops and Products. 2016; 83: 603-6.

18. Esmaielpour B, Rahmanian M, Heidarpour $\mathrm{O}$ and Shahriari MH. Effect of Vermicompost and Spent Mushroom Compost on the Nutrient and Essential Oil Composition of Basil (Ocimum basilicum L.). J. Essential Oil Bearing Plants. 2017; 20: 1283-92.

19. United States Environmental Protection Agency (USEPA), Control of Pathogens and Vector Attraction in Sewage Sludge. EPA 815R-06e002 Revised edition, Washington, DC, US EPA. 2003, p: 165.

20. British Pharmacopoeia, HMSO. (United Kingdom, London). 1993, p: 10952.

21. Adams RP. Identification of Essential Oil Components by Gas Chromatography/Quadrupole Mass Spectroscopy, Forth Edition, Allured Publishing Corporation, CarolStream, IL. 2007, p: 804.

22. Westerman RL. Soil Testing and Plant Analysis. Third Edition, Book Series No. 3, SSSA, USA 1990, p: 784.

23. Peters J, Combs S, Hoskins B, Jarman J, Kovar J, Watson M, Wolf A and Wolf N. Recommended methods of manure analysis. University of Wisconsin Cooperative Extension Publishing: Madison, WI. 2003, p: 57.

24. United States Environmental Protection Agency (USEPA) 503 standards for the use or disposal of sewage sludge, Fed. Regis, 58, 9387. 1993, p: 29. 
25. Page A, Miller R and Keeney D. Methods of soil analysis. Part 2. Chemical and microbiological properties. American Society of Agronomy. Soil Science Society of America. Madison, Wisconsin, DC. USA. 1982, p: 1143. 26. Dane JH and Topp GC. Methods of soil analysis. Part 4. Physical methods. Soil Science Society of America. Madison, Wisconsin, USA. 2002, p: 1692.

27. Ghanati F, Abdolmaleki P, Vaezzadeh M and Rajabbeigi E and Yazdani M. Application of magnetic field and iron in order to change medicinal products of Ocimum basilicum L. The Environmentalist. 2007; 27: 429-34.

28. Hussein M, El-Sherbeny S, Khalil M, Naguib $\mathrm{N}$ and Aly S. Growth characters and chemical constituents of Dracocephalum moldavica L. plants in relation to compost fertilizer and planting distance. Scientia Horticulturae. 2006; 108: 322-31.

29. Zheljazkov VD, Craker LE and Xing B. Effects of $\mathrm{Cd}, \mathrm{Pb}$, and $\mathrm{Cu}$ on growth and essential oil contents in dill, peppermint, and basil. Environmental and Experimental Botany 2006; 58: 9-16.

30. Sinha S, Sinam G, Mishra RK and Mallick S. Metal accumulation, growth, antioxidants and oil yield of Brassica juncea L. exposed to different metals. Ecotoxicology and Environmental Safety 2010; 73: 1352-61.

31. Patel A and Patra D. Influence of heavy metal rich tannery sludge on soil enzymes visà-vis growth of Tagetes minuta, an essential oil bearing crop. Chemosphere 2014; 112: 323-32. 32. Najafi N, Mardomi $S$ and Oustan S. Changes in DTPA extractable copper, iron, manganese and zinc after waterlogging and application of sewage sludge and animal manure in two different soils. Iranian Journal of Soil and Water Research. 2012; 43 (1): 9-22. 33. Mahmoudi S, Najafi $\mathrm{N}$ and Reyhanitabar A. Effect of soil moisture and sewage-sludge compost on some soil chemical properties and alfalfa forage macronutrients concentrations in greenhouse conditions. Journal of Science and Technology of Greenhouse Culture 2015; 6 (22): 37-55.

34. Mohamed B, Mounia K, Aziz A, Ahmed H, Rachid B and Lotfi A. Sewage sludge used as organic manure in Moroccan sunflower culture: Effects on certain soil properties, growth and yield components. Science of the Total Environment 2018; 627: 681-8.

35. Mahmoudi S, Najafi $N$ and Reyhanitabar A. Effects of soil moisture and sewage sludge compost on leaf chlorophyll index and some growth traits of alfalfa in greenhouse conditions. Journal of Science and Technology Greenhouse of Culture. 2015b; 5 (20): 207-20 [In Persian].

36. Singh R and Agrawal M. Potential benefits and risks of land application of sewage sludge. Waste Management 2008; 28: 347-58.

37. Kchaou R, Baccar R, Bouzid J and Rejeb $\mathrm{S}$. The impact of sewage sludge and compost on winter triticale. Environmental Science and Pollution Res. 2017; 25 (19): 18314-9.

38. Díaz-Maroto MC, Sánchez Palomo E, Castro L, Viñas $G$ and Pérez-Coello MS. Changes produced in the aroma compounds and structural integrity of basil (Ocimum basilicum L.) during drying. Journal of the Science of Food and Agriculture. 2004; 84: 2070-6.

39. Klimankova E, Holadová K, Hajšlová J, Čajka T, Poustka J and Koudela M. Aroma profiles of five basil (Ocimum basilicum L.) 
cultivars grown under conventional and organic conditions. Food Chem. 2008; 107: 464-72.

40. Prasad A, Kumar S, Khaliq A and Pandey A. Heavy metals and arbuscular mycorrhizal (AM) fungi can alter the yield and chemical composition of volatile oil of sweet basil (Ocimum basilicum L.). Biology and Fertility of Soils. 2011; 47: 853.

41. Kasali AA, Eshilokun AO, Adeola S, Winterhalter P, Knapp H, Bonnlander B and Koenig WA. Volatile oil composition of new chemotype of Ocimum basilicum L. from Nigeria. Flavour and Fragrance J. 2005; 20: 45-7.

42. Kumar A, Shukla R, Singh P, Prakash B and Dubey NK. Chemical composition of Ocimum basilicum L. essential oil and its efficacy as a preservative against fungal and aflatoxin contamination of dry fruits. International Journal of Food Science and Technol. 2011; 46: 1840-6.

43. Figueiredo AC, Barroso JG, Pedro LG and Scheffer JJ. Factors affecting secondary metabolite production in plants: volatile components and essential oils. Flavour and Fragrance Journal. 2008; 23: 213-26.

44. Rodrigues L, Póvoa O, Teixeira G, Figueiredo AC, Moldão $\mathrm{M}$ and Monteiro A. Trichomes micromorphology and essential oil variation at different developmental stages of cultivated and wild growing Mentha pulegium L. populations from Portugal. Industrial Crop and Products 2013; 43: 692-700.

45. Bolechowski A, Moral R, Bustamante M, Bartual J, Paredes C, Pérez-Murcia MD and Carbonell-Barrachina AA. Winery-distillery composts as partial substitutes of traditional growing media: Effect on the volatile composition of thyme essential oils. Scientia Horticulturae 2015; 193: 69-76.

46. Zheljazkov VD and Warman PR. Sourceseparated municipal solid waste compost application to Swiss chard and basil. $J$. Environmental Quality 2004; 33: 542-52.

47. Miguel MG, Cruz C, Faleiro L, Simoes M, Figueiredo AC, Barroso JG and Pedro LG. Foeniculum vulgare essential oils: chemical composition, antioxidant and antimicrobial activities. Natural Product Communications 2010; 5: 319-28.

48. Fukasawa-Akada T, Kung S and Watson JC. Phenylalanine ammonia-lyase gene structure, expression, and evolution in Nicotiana. Plant Molecular Biol. 1996; 30: 711 -22.

49. McCallum JA and Walker JRL. Phenolic biosynthesis during grain development in wheat: changes in phenylalanine ammonialyase activity and soluble phenolic content. $J$. Cereal Science 1990; 11: 35 - 49.

50. Wen PF, Chen JY, Kong WF, Pan QH, Wan SB and Huang WD. Salicylic acid induced the expression of phenylalanine ammonia-lyase gene in grape berry, Plant Science 2005; 169: $928-34$.

51. Santoro MV, Zygadlo J, Giordano $\mathrm{W}$ and Banchio E. Volatile organic compounds from rhizobacteria increase biosynthesis of essential oils and growth parameters in peppermint (Mentha piperita L.). Plant Physiol and Biochem. 2011; 49: 1177-82. 